\title{
MUNICIPAL INTEGRATED COASTAL GOVERNANCE APPROACH: COMPLIMENTARY DISCIPLINARY INSTRUMENTS AND COLLABORATION PRE-CONDITIONS
}

\author{
(D) Maija Stokmane ${ }^{1}$, MSc.env.sc.; Anita Lontone-Ievina², MSc.env.sc.; \\ Raimonds Ernsteins ${ }^{3}$, Prof. \\ 1,2,3 Environmental Science Department, University of Latvia, Riga, Latvia
}

\begin{abstract}
Municipal coastal governance practice also in Latvia has various limitations, and taking into account growing climate change adaptation challenges, new understanding and new approaches are to be studied and tested. Overall study frame is based on research-and-development approach. The aim of the research was to study how municipal coastal governance is functioning in practice, particularly, in the relation to the coastal dune protection zones $(150 / 300 \mathrm{~m})$ and further coastal territory behind that, applying whole list of governance instrument groups political/legal, planning, and especially institutional instruments, also financial, infrastructure and, last but not least, coastal communication instruments. This was done via research-and-governance frame of the three coastal governance dimensions - governance content, stakeholders (governance segments) and governance instruments, realized in Jurmala municipality as especially nature-culture rich and due to tourist attraction also sensitive coastal pilot territory at the Latvia coast. Case study research methodology applied (document studies, observation and stakeholder's interviews) were approving pre-study understanding, based on previous coastal governance studies, that also this territory with international coastal resort status and well developed municipal administration capacities have limited success on integrated coastal management (ICM) approach implementation and, subsequently, there are requirements on further development of disciplinary instruments and also collaboration governance as ICM preconditions. An integrated ICM approach was internationally designed and approved also for EU coastal countries, since comprehensive requirement to manage the adequate governance of the coast as complex socio-ecological system, but old shaped long existing traditional disciplinary/branch approaches of former and formal municipal planning and management does not really permit necessary innovations with cross-sectorial and cross-level integration perspectives. However, also orientation towards re-use and/or re-development of disciplinary ICM instruments, especially, to be designed and realized as complementary as possible and collaboration governance developments shall be seen as necessary pre-conditions for ICM adequate development.
\end{abstract}

Key words: Jurmala municipality; socio-ecological system; integrated coastal management; environmental governance dimensions; coastal governance review.

JEL codes: Q20, Q57, Q58

\section{Integrated versus disciplinary approaches for municipal coastal governance}

Integrated coastal management (ICM) practices are known around the world starting from 1970-ties, however the process done so far and success reached in ICM implementation among different coastal countries is very variable (Forrest, 2006). Within the present study we examined the coastal governance practices and ICM problems in the European countries.

ICM legislation and strategies. There are different opinions among European countries regarding the legislation of ICM. Many countries have no specific legislation relating to ICM, and the existing laws and regulation are being used to support ICM (Burbridge, 2004). For example, the Netherlands has concluded that no new system for ICM is needed for them but that it will form part of a national spatial planning strategy (Portman et al., 2012). Also, in Germany many of the ICM principles have already been implemented through existing legal instruments, and those instruments have already imposed "good management" of the German coastal zone (O' Hagan, Ballinger, 2009). On the contrary, however, France emphasizes the importance of intensifying the ICM implementation at the local level, including local capacity building, and the establishment of a national council for implementing ICM (Portman et al., 2012). The

1 Telephone: +371 22161440. E-mail address: ms08165@lu.Iv

2 Telephone: + 371 29923106. E-mail address: anita.lontone@gmail.com

3 Telephone: +371 29476620. E-mail address: raimonds.ernsteins@lu.Iv 
positive thing is that in many coastal countries the ICM strategies are currently being prepared. It has been shown that ICM principle implementation is more successful in those countries which have ICM strategy (Thetis, 2011).

Stakeholder involvement. ICM works best where a broad body of public participates in the ICM process, so it is very important to enable stakeholders to take an active part in the coastal management (Burbridge, 2004). Nevertheless, in a lot of coastal countries very low attention has been given to effective stakeholder involvement at regional and local levels. Also, there is need for actions to support institutional coordination among levels and sectors (Thetis, 2011). However, one of the positive examples comes from Norway. The coastal zone management in Norway is formally structured in a way that involves a wide range of different user groups and stakeholders in the planning processes which not only improves the public participation and makes this process more democratic but also helps to collect the knowledge about the coastal territory which can be later used by the coastal zone planner (Buanes et al., 2004).

Science and policy integration. There are several types of integration that can be achieved by the ICM process. However, one of the most neglected dimensions of integration is the crossing of coastal science and policy, because there still exists a gap between these two (Thetis, 2011; Portman et al., 2012). The problem is that scientists conduct their research without considering the needs of decision-makers but the decision-makers make their decisions on political premises (Thetis, 2011). Unfortunately, there seem to be very few opportunities how to enhance the integration between science and policy. One of the potential mechanisms that can bring scientific study and evidence into decision-making process is the environmental impact assessment (EIA). But that is not enough, and some new mechanisms would be really necessary (Portman et al., 2012).

Coastal monitoring. One of the factors that hinder the establishment of ICM practices, is the shortage of data on coastal systems and how they function (Burbridge, 2004). But the lack of coastal information exists because of the absence of monitoring in the coastal countries (examples: France, Italy) (Deboudt, 2012; Buono et al., 2015). In contrast, however, some countries have established a very successful monitoring system. Perhaps one of the best examples of ICM monitoring at the municipal level comes from Greece. The Kavala Municipality of Greece has developed a new instrument for the costal governance - the so-called ICM Observatory. This Observatory collects, analyses and processes past, present and forecasted ICM-datasets collected from a variety of sources. The user can access to a huge amount of information about the coastal zone through this system plus actively take part in the information exchange. This coastal Observatory highly enhances stakeholders' collaboration, promotes public participation, promotes the distribution of information among stakeholders, and provides reliable datasets to scientists (Kalpakis et al., 2018).

Much focus on nature dimension. Another point is that the experience of many Baltic Sea Region EU countries with ICM is often limited to small-scale projects with a nature conservation focus - for example, the basis of an ICM is usually formed by habitat and species protection while other issues (e.g. human health, employment, restructuring of agriculture) are neglected (Burbridge, 2004). So, also at the later stage, the problem is that ICM is still often being seen as a green initiative that fails to take adequate account of socio-economic conditions (O' Hagan, Ballinger, 2009) and the whole socio-ecological systems approach (Hopkins, 2012, Ernsteins, 2017bc).

National framework of coastal governance in Latvia. At the national level, several principal documents should be mentioned regarding the coastal area of Latvia: "Sustainable Development Strategy of Latvia until 2030"; "National Development Plan for 2014-2020"; "Environmental Policy Guidelines for 2014-2020" and different other documents in which the coastal issues have been partly integrated. It is 
also important to mention that contrary to the European Union's asking for the development of national ICM strategies, Latvian government stated that ICM should be integrated into the mandatory plans of the coastal municipalities. However, this approach was difficult to implement due to various objective and subjective reasons (Ernsteins et al., 2015). Then, after the long-lasting and active calls from the academic environment, local governments and other interest groups, the national position was finally changed and, instead of the theoretically correct coastal integration approach, it was decided to develop also the coastal sectorial planning. As a result, the following two documents have been prepared: (1) "Strategy for Coastal Spatial Development for 2011-2017"; and later on (2) "National Long-Term Thematic Plan for the Coastal Area of the Baltic Sea" (or Coastal plan, 2016). Latvia now has also a separate national level long-term spatial development planning document of the sea waters - the Maritime Spatial Plan (2019).

Local/municipal framework of coastal governance. Overall, there are four municipalities in Latvia out of 17 in total that have prepared some kind of local coastal area development plans, so called, thematic plans. One thematic plan - "Development of the beach and the coast of the city of Liepaja" (2015) - has been fully dedicated to the sea coast, while the rest of the plans - "Jurmala City Water Resources Protection Action Plan (2016)", "Public Water and Maritime Coastal Zone Management Plan (2017)" approved by Carnikava rural municipality, and "Thematic plan of water areas and embankments of Riga (2017)" - are plans on public waters and their coastal infrastructure, having only some enclosure of coastal territories/waters too. In addition, within the framework of the Pan Baltic Scope project, a pilot thematic planning project has been developed for Salacgriva municipality with the aim to provide proposals for integrated planning and development of the coastal waters ( $2 \mathrm{~km}$ zone seawards), coordinating the coexistence of sea-land use interests.

Jurmala municipality is coastal city, spread along Riga Bay of the Baltic Sea, being semi-urban area $\left(100 \mathrm{~km}^{2}\right)$ with almost 60000 inhabitants, conveniently located $25 \mathrm{~km}$ from Riga, the capital city of Latvia, and geographically looking as stretched peninsula with about $30 \mathrm{~km}$ of the river Lielupe coast from south and about $25 \mathrm{~km}$ sandy coastal beach from north. The whole territory is rich with many natural resources, besides coastal dune pine forests having sulphide-containing mineral waters and mud used already since early $19^{\text {th }}$ century and creating background for largest health and recreation resort city on the Baltic coast (more than a hundred thousand tourists per year). Having growing anthropological pressure, Jurmala has to be seen as coastal and environmentally sensitive municipality, stressing importance of environmental protection and adequate development management.

\section{Methodological framing for Jurmala municipality case study research}

Study area included the whole territory of this peninsula shape (between sea and the river Lielupe) municipality, starting from $150 / 300 \mathrm{~m}$ coastal dune protection belt up to $5 \mathrm{~km}$ limited economic activity belt (both belts according to the national coastal protection legislation) and beyond this, even peninsula is rather narrow (incl. area of just 300 m distance between sea and river). The Case Study Research methodology was applied in Jurmala coastal city, being framed via Research-and-Development approach, subsequently including complementary set of research methods - document studies, stakeholder interviews, coastal site observations.

Document studies included inspection and analysis of all the range of municipal statutory, voluntary planning as well as all local legislation/regulations and everyday management documents, related to sustainability/environmental/coastal (cross-sectorial) issues, but also covering issues of all main stakeholder groups and their activities. Further on, observation studies were organized along the coast approaching main institutional, infrastructure and utilities and services management related territories, 
objects. To complement mentioned studies done, there were realized 5 semi-structured interviews with experts on ICM in Latvia in general and Jurmala case especially, but the main emphasis was laid on altogether 37 deep semi-structured interviews being conducted with representatives of all main local interest groups and locally-based national/regional stakeholders, which were grouped and studied also by five governance segments (Ernsteins et al., 2017a), including:

- Municipal administration segment (elected councillors, all administration level employees);

- National/regional level segment institutions (Environmental Ministry and their subordinate services/agencies, particularly, Kemeri National Park, partially covering also Jurmala municipality);

- Business segment (locally based producing/services entrepreneurs);

- Mediator segment (media, formal/non-formal education, NGO, science-based representatives);

- Inhabitants/local householders' views were studied via several secondary sources, e.g. bi-annual municipal questionnaires, but also several randomly chosen inhabitants were interviewed by the same semi-structured questioner format as other stakeholders.

During the study, these complementary used methods application was based on the semi-structured questioner content and so the coastal governance issues in Jurmala municipality were analysed within designed research-and-governance framework of the three environmental/coastal/development governance dimensions (Ernsteins, 2017c): governance sectors; governance segments

(stakeholders); governance instruments. This complementary three-dimension approach was giving answers to the three key questions of the coastal governance, namely: what to govern in which horizontal content sectors; who are/will be governing this as which departments/sectors and other stakeholders' groups are/might be involved; how this governing could be done as which instruments are/would be applied and eventually combined, complemented.

\section{Case study research in Jurmala municipality}

\subsection{Coastal dune protection belt: legal and planning frame}

Since the acceptance of the Land Management Law in Latvia (in 2014), there has a new responsibility emerged for the Latvian coastal municipalities - now they must also govern the marine coastal waters (up to $2 \mathrm{~km}$ in the sea from the coast), as well as the land part of the coastal area (a territory between the marine coastal line and the place which is reached by the highest waves of the sea). In order to better understand the new responsibilities of the coastal municipalities, during this particular study a scheme of the coastal zone was prepared, in which there has been simply demonstrated the expressions and the mutual interactions between the three laws of Latvia which somehow define the coastal zone of the country, namely the Land Management Law, the Protection Zone Law and the Fishery Law (Fig. 1).

The Land Management Law determines several important things about the coast of the Baltic Sea, including that: (1) it lists the principles and requirements of the land use and its protection within the coastal zone; (2) it prescribes the ownership rights of the coastal zone; and also (3) it defines the spatial structure of the coast. The Protection Zone Law, in turn, represents the nature protection interests in the coastal zone - this law lists all the restrictions that exist on the coast of the Baltic Sea and the Gulf of Riga, and it specifies different types of protection zones in the coastal area. Finally, the Fishery Law determines the specific zone (called the towpath) in the coastal area which is a strip of land along the coastline intended for pedestrians, and according to this law, pedestrians have rights to access and use the towpath freely and without any charge. 


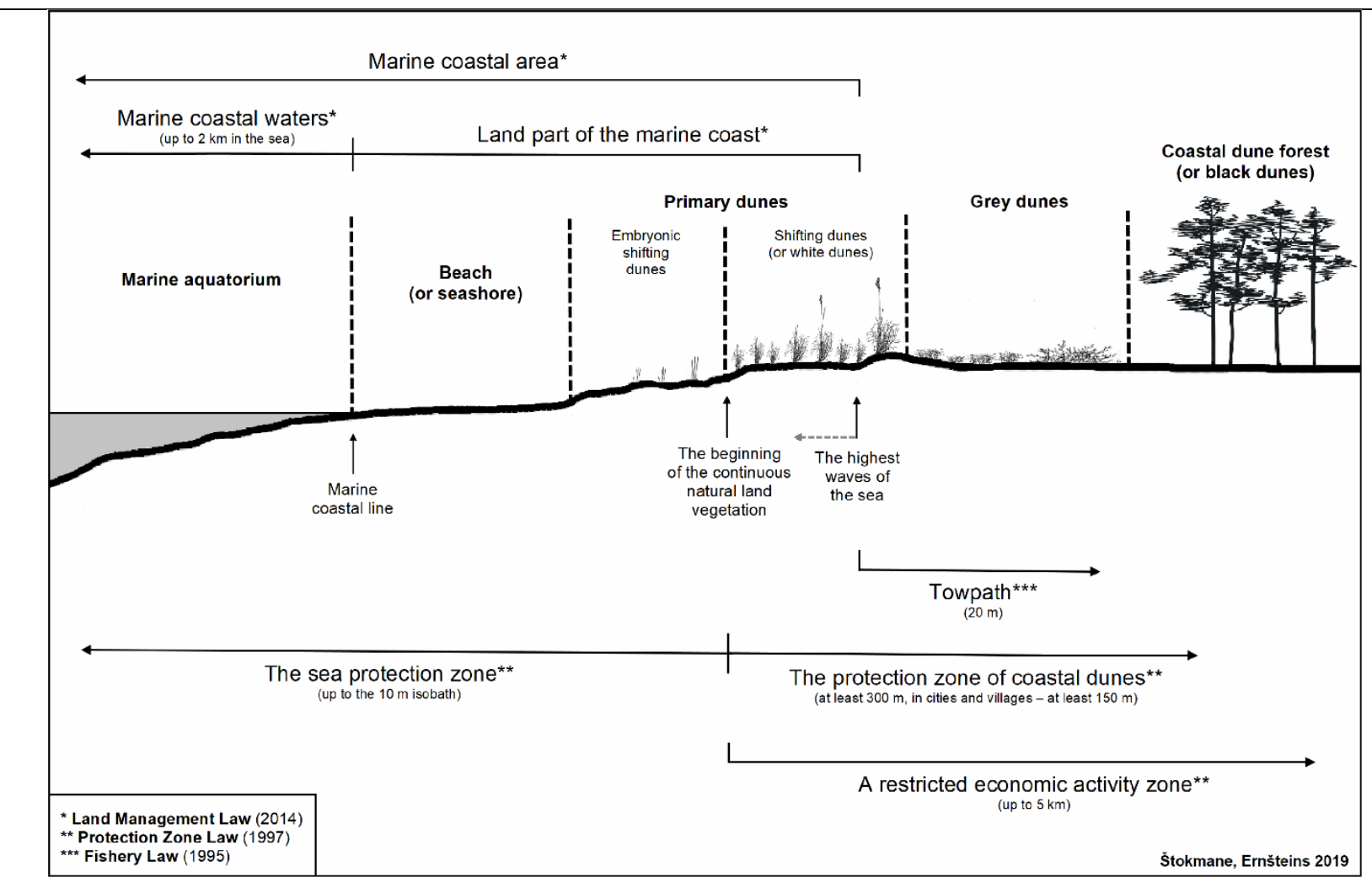

Fig. 1. A simplified scheme about the coastal zone definition and the local municipality's ownership rights of the coast according to the following laws of Latvia: The Land Management Law; the Protection Zone Law; the Fishery Law

It should be emphasized, however, that the prepared coastal zone scheme is a simplified version of the coastal structure, which mainly highlights all the zoning parameters (e.g. specific distances and boundaries) of the coastal territory which are defined by the mentioned laws. The scheme only qualitatively demonstrates the aspects of the natural environment in the coastal area, but it obviously does not show the socio-economic factors which also take place in the coastal area. Nevertheless, the complex nature of the coastal zone and, consequently, the problems of managing such a socio-ecological system (SES) are evident in this particular scheme.

\subsection{Main coastal problem-orientation: the coastal protection belt and beyond}

Within the "Strategy for Coastal Spatial Development 2011-2017" the following coastal definition can be found - the coast is the contact zone of the Baltic Sea and the inland where: geological processes of the seashore take place (erosion and accumulation), where there is a unique marine and coastal landscape constituted by the beach, steep shores, estuaries, rand meadows, dunes, lagoon lakes, lighthouses, piers, ports, port cities, villages and individual farms, where the lifestyle (fishing at sea, fish processing, gathering of seaweed) and the cultural heritage (buildings, dialects, traditions etc.) differ from those of the inland.

In this definition, like in the real life, no concrete boundaries can be drawn on how far from the coastal line we can think we need to perform coastal planning and management, so there are different assessments and approaches in international practice, based on the principle of bio-geographical ecosystems that the coastal area is as large as the inland influences the sea and its coast. But in local planning practice, two basic approaches in coastal planning and management are established - the nationally determined strictly protected coastal dune zone (150 or $\mathbf{3 0 0}$ m), and the administrative territory of the local municipality 
as a coastal territory with its own administrative government that can organize coastal protection and management.

However, in practice, in the simplified case of coastal zone/area we mean at least the Coastal dune protection zone (Protection Zone Law, 1997), i.e., the zone from the marine coastal line, including the beach, dunes, area behind the dunes (including forest, meadows, nature areas) and the first part of the populated area in total at least $\mathbf{3 0 0} \mathbf{~ m}$ inland from the first sea wave (but in cities/villages up to $150 \mathrm{~m}$ in the sense of the law, but in development planning practice, basically, to the first street that is parallel to the sea); however, depending on the terrain and the impact on the marine environment, the coastal zone could be viewed more widely, including the territory up to $5000 \mathrm{~m}$ landwards which is the restricted economic activity zone.

In the municipality this means that all this is examined in detail and integrated into the statutory territory plan, which is approved in public consultation and by the Ministry of Environmental Protection and Regional Development of the Republic of Latvia, and the law strictly requires and the State Environmental Service inspectors also regularly control the legal compliance. Therefore, in general the protection of these $150 / 300 \mathrm{~m}$ coastal dune protection zones is ensured at the national level, however the public participation is also important here, including the public environmental inspectors who are active in some Latvian municipalities to prevent the dune riding, etc. Also, in order to additionally protect this coastal dune zone and reduce the anthropogenic pressure (especially in popular tourist destinations, etc.), the state developed a Coastal Thematic Plan (2016) which is based on public infrastructure development as a basic tool for coastal governance, and in cooperation with municipalities is developing and providing the improvement and reconstruction of coastal infrastructure within 60 selected territories and 25 priority territories.

It is also important to mention the development of voluntary local planning instruments, namely, the EU 2002 setting of National ICM Strategies was gradually managed to achieve (under the stakeholder pressure) at the national level by the development of coastal cross-sectoral coastal infrastructure (partially alike ICM-type) planning documents at the national level (2011 and then 2016 Coastal National Plans), but also to actualize this issue at the local municipality level too. Here are to be mentioned those four from 17 coastal municipalities in Latvia having prepared the local coastal issues related development plans: Liepaja city municipality with full scope coastal thematic development plan, Jurmala and Riga cities with their water resource and coastal infrastructure plans, as well as, the same for Carnikava rural municipality.

But coastal governance is not limited to $150 / 300 \mathrm{~m}$, because it is necessary to assess the whole coastal municipality and its development from the basic principle of coastal governance, ICM requirement: the horizontal integration of thematic sectors/fields and their vertical inter-level integration, based on the cooperation of all key stakeholders and the integration of governance instruments, culminating in the ICM as an inter-sectoral planning document or the integration of this ICM approach into municipal statutory development planning documents. And in Latvia they are - the strategic planning up to 25 years (Sustainable Development Strategy), and medium-term 7-year planning (Development Programme and Spatial Plan).

Finally concluding, the problems described are related first of all to the two main issues: (1) the legal instrument further developments and enforcement dependent on both, the national level and the local level administrations; and (2) coordinated managerial municipal efforts of many and various departments in eventual partnership with other main stakeholders and general public. 


\subsection{Coastal governance instruments: six instrument groups in Jurmala}

In addition to discussed institutional instruments, five other instrument groups (Tab. 1) are distinguished, namely: (1) Political and legislative instruments (for example, different normative acts); (2) Planning instruments (mandatory and voluntary planning documents); (3) Economic and financial instruments (money-related tools, e.g. municipal budget, taxes); (4) Infrastructural instruments (different infrastructure objects on the coastal zone); and (5) Communication instruments (information, education, public participation, coastal-friendly behavior). In the Tab. 1 there is presented this whole list of the most typical/related instrument examples of each of six instrument groups.

Table 1

The list of coastal governance instruments in Jurmala, divided in six groups

\begin{tabular}{|c|c|c|}
\hline Instrument groups & Examples & List of instruments in Jurmala municipality \\
\hline $\begin{array}{l}\text { Political and } \\
\text { legislative } \\
\text { instruments }\end{array}$ & $\begin{array}{l}\text { Normative } \\
\text { acts, binding } \\
\text { regulations }\end{array}$ & $\begin{array}{l}\text { - Binding regulations No. } 3 \text { "On the use of Jurmala city beach and } \\
\text { swimming areas" } \\
\text { - Binding regulations No. } 20 \text { "Jurmala port regulations" } \\
\text { - Binding regulations No. } 27 \text { "On the use of the river Lielupe in the } \\
\text { administrative territory of the city of Jurmala" }\end{array}$ \\
\hline $\begin{array}{l}\text { Planning } \\
\text { instruments }\end{array}$ & $\begin{array}{l}\text { Development } \\
\text { planning } \\
\text { documents } \\
\text { (mandatory + } \\
\text { voluntary) }\end{array}$ & $\begin{array}{l}\text { - Sustainable Development Strategy 2010-2030 } \\
\text { - Development Program 2014-2020 } \\
\text { - Spatial (territorial) Plan 2009-2022 } \\
\text { - Municipal annual public report } \\
\text { - Tourism Development Strategy 2007-2018 } \\
\text { - Tourism Development Action Plan 2018-2020 } \\
\text { - Resort Concept 2009-2018 } \\
\text { - Water Resources Protection Action Plan 2016-2020 }\end{array}$ \\
\hline $\begin{array}{l}\text { Administrative and } \\
\text { institutional } \\
\text { instruments }\end{array}$ & $\begin{array}{l}\text { Commissions, } \\
\text { committees, } \\
\text { boards, } \\
\text { departments, } \\
\text { capital } \\
\text { companies }\end{array}$ & $\begin{array}{l}\text { - Beach Management Commission } \\
\text { - Committee on Development and Environmental issues } \\
\text { - Committee on Tourism and Resortology } \\
\text { - Urban Planning Department } \\
\text { - Urban Economy and Improvement Department } \\
\text { - Environmental Department } \\
\text { - Municipal Property Department } \\
\text { - Municipal Police } \\
\text { - Jurmala City Museum + its branch - Open Air Museum } \\
\text { - Jurmala port (or Lielupe port) }\end{array}$ \\
\hline $\begin{array}{l}\text { Economic and } \\
\text { financial } \\
\text { instruments }\end{array}$ & $\begin{array}{l}\text { Budget, } \\
\text { taxes, fines }\end{array}$ & $\begin{array}{l}\text { - Municipal basic budget } \\
\text { - Natural resources tax } \\
\text { - Initiative projects } \\
\text { - Attraction of European funds }\end{array}$ \\
\hline $\begin{array}{l}\text { Infrastructural } \\
\text { instruments }\end{array}$ & $\begin{array}{l}\text { Infrastructure } \\
\text { elements }\end{array}$ & $\begin{array}{l}\text { - Pathways to beach } \\
\text { - Toilets, rubbish bins } \\
\text { - Benches, changing cabins } \\
\text { - Playgrounds and sports fields } \\
\text { - Rescue service } \\
\text { - Information signs and information stands } \\
\text { - Educational nature trails } \\
\text { - Bicycle paths }\end{array}$ \\
\hline $\begin{array}{l}\text { Communication } \\
\text { instruments }\end{array}$ & $\begin{array}{l}\text { Information } \\
\text { sources, } \\
\text { educational } \\
\text { institutions }\end{array}$ & $\begin{array}{l}\text { - The website of the municipality } \\
\text { - Newspapers ("Jurmalas Avize", "Jurmalas Vards") } \\
\text { - Municipal social network accounts (Facebook, Twitter) } \\
\text { - Tourism information centre } \\
\text { - Outdoor information stands } \\
\text { - Jurmala eco-schools } \\
\text { - Inhabitant surveys and public consultations } \\
\text { - Beach clean-ups } \\
\text { - Dune stabilization measures } \\
\text { - Blue Flag programme (from } 1998 \text { till 2019) }\end{array}$ \\
\hline
\end{tabular}




\subsection{Coastal governance in Jurmala: Institutional structure and cooperation}

Jurmala, as any other Latvian local municipality, has management structure, which could be divided between four vertical levels of governance:

1) Municipal legislative institutions;

2) Municipal executive institutions;

3) Institutions subordinated to the municipality;

4) Municipal capital companies.

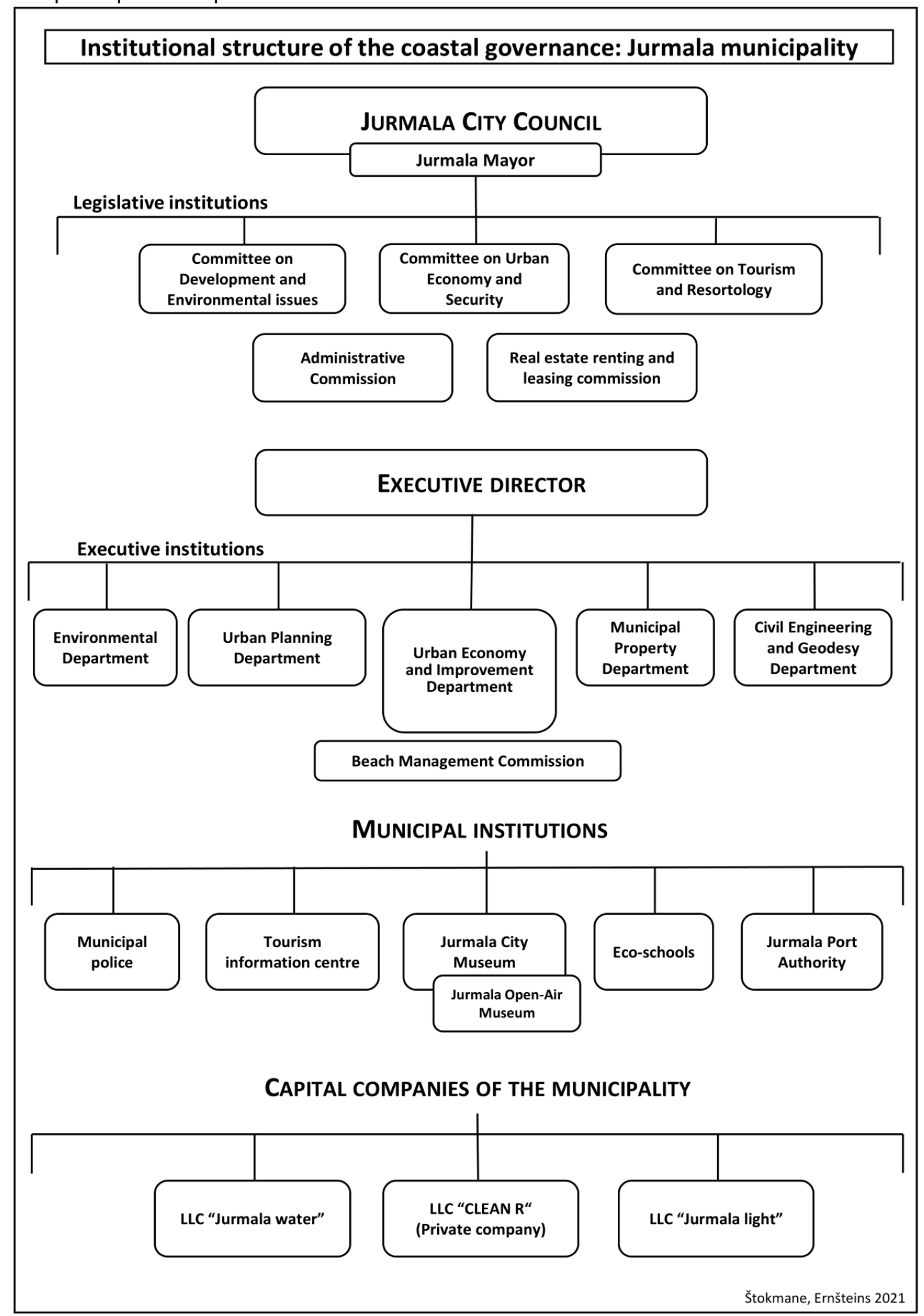

Fig. 2. Jurmala municipality institutional instruments for coastal governance 
The municipal institutional structures that all are at least involved into the work on coastal issues, are shown in Fig. 2. Vertical coordination or integration as well as horizontal integration between the structural units of each level and in eventual partnership with outside stakeholders are very important to successfully govern the coastal area.

There are many institutions to be seen involved, but the structure can be recognized as fragmented in the Jurmala municipality and vertical and horizontal collaboration importance could not be underestimated. Within municipal structures there are to be seen also the public and stakeholder participations from outside, but in this relation there shall be necessary to study also the whole list of all other coastal governance instruments and their eventual complementarity.

\section{Discussion on innovation complementary/disciplinary instruments}

The Jurmala case was compared to other coastal municipalities in Latvia, where similar studies have been conducted. Jurmala was compared with two other coastal cities (Liepaja and Ventspils) as well as with one rural municipality (Salacgriva).

Liepaja city is the most progressive coastal municipality in Latvia, which is one step ahead of all the other coastal municipalities. One of the main reasons for this is that the Liepaja municipality has developed a unique thematic plan for the coast - "Development of the beach and the coast of the city of Liepaja", which serves as a multi-functional and complementary instrument that allows for a more successful governance of the coastal territory. This plan is the first of its kind in Latvia, which is a very important instrument for the further development of integrated coastal management. It should also be emphasized that Liepaja municipality has the first beach in Latvia, as well as the only beach in the Baltics, which is fully-fledged for people with special needs (Lerhs, 2017).

Ventspils city is one of the best municipalities on coastal governance in Latvia too. Ventspils municipality has a well-equipped and successful Environmental Department, which has a relatively large capacity, so the coastal problems are solved in a complex manner. Although separate coastal planning documents have not been prepared in the municipality, all information and development perspectives related to the coast are included in the three mandatory planning documents. In addition, another positive aspect is that Ventspils municipality put emphasis on the involvement of all target groups and the development of communication between them (Lerhs, 2017).

A similar study to the present one was conducted also in Salacgriva municipality where governance sectors, segments and instruments were analysed. The obtained results in Salacgriva were quite similar to those for Jurmala municipality, and they were as follows: (1) The normative and other planning and management documents in Salacgriva municipality do not fully reflect coastal issues and do not conceptualize the development of the coastal system; (2) Target groups have a limited understanding of the coast as a socio-ecological system and make little contribution to municipal coastal governance; and (3) The wide range of municipal instruments does not fully cover all the coastal governance issues (Ernsteins et al., 2020a). The results of mentioned project were also partially adapted in the Jurmala ICM case studies and there was seen clear confirmation.

Recommendations for coastal governance in Latvia. In order to better address current and future challenges in the coastal zone, it would be necessary to gain a much better understanding of the specifics and characteristic features of the coastal territory - it would be important to monitor the coastal zone and carry out different long-term scientific studies, in order to find out how the coastal ecosystem functions, how economic activities interact with the various components of the coastal ecosystem etc. Therefore, the establishment of scientifically substantiated and at the same time easy-to-apply and easy-to-interpret 
municipal coastal monitoring as well as the preparation and implementation of coastal indicator system. Ideally, the monitoring should, at least partly, take the form of public monitoring ("Citizen science" approach), since this would not only allow the explore the coastal situation in the given territory, but it would also create greater opportunities for citizens to involve in the governance processes.

Successful and progressive development of coastal governance can only be provided if there is cooperation with all the main target groups. Therefore, it would be important to make a greater use of public participation instruments. Besides, it would be important to develop both types of target group involvement - the Top-down involvement as well as the Bottom-up involvement. It would be especially important if the municipality supported the Bottom-up approach initiatives and encouraged the public to become much more involved in the municipal processes. It would also be crucial for the municipality to cooperate more actively with various environmental NGOs when solving coastal problems, since in this way the municipality could fully delegate certain coastal issues to an NGO, thus facilitating its own work. At the same time, it would also create more trust in the municipality.

Taking into account the growing environmental problems in coastal areas, special emphasis should be placed on the crucial role of coastal communication in the coastal governance. Communication is considered to be one of the preconditions, principles and instruments of good governance. The great advantage of coastal communication is that it is the cheapest and easiest way for a municipality to think about the sustainability of its coastal resources, and in which various target groups can also be successfully involved, thus facilitating the work of the municipality itself. In order to provide the successful coastal communication, as well as to achieve the highest communication efficiency, it would be important for the municipality to fully and complementarily apply all four components of coastal communication information, education, public participation, as well as environmentally friendly behavior.

During this comprehensive study of coastal governance in Jurmala municipality, the first version of an innovative and comprehensive coastal planning document - Coastal Governance Outlook (CGO) - was also developed (Ernsteins et al., 2020b). Jurmala CGO is a development planning document of disciplinary approach, based on monitoring overview of the three coastal governance dimensions (governance content, segments and instruments) including both environmental and socio-economic aspects, representing so the overall situation with coastal governance in the corresponding coastal municipality. Although additional research is still needed, it seems that the already-developed first version of the "Jurmala CGO" provides a new systematic overview and cumulative information on the coastal governance situation in Jurmala, so it is thought that Jurmala CGO would be that missing one instrument for integrating coastal issues into all other Jurmala municipal planning documents (Ernsteins et al., 2020b).

\section{Conclusions}

National as well as municipality-based integrated coastal governance approach as internationally widely recommended for its application practice into traditional municipal branch/sector-oriented management, unfortunately could not alone fulfil all those necessarily coastal governance functions, particularly, for its horizontal and vertical integration, and stakeholders participation integration, due to various existing administrative structural and processual limitations, and, subsequently, there is to be seen requirements for additional and innovative instruments and processes. This could be viewed as pre-conditional requirements for implementation of integrated coastal governance approach.

Subsequently, first pre-condition to be mentioned are to be oriented towards re-use and/or redevelopment of disciplinary ICM instruments, especially, to be designed and realized as complementary as possible. And for the second main pre-condition is to be mentioned collaboration governance 
development, focusing on all three governance dimensions - content/governance sectors collaboration, collaboration between instruments available or to be designed, and, obviously, stakeholders' real collaboration development.

Taking into account that the coastal municipalities are having limited success with coastal integration into their development planning documents and institutional management practice -there is space for some instruments to make this integration easier. One of such instruments could be the Coastal Governance Outlook (CGO). The CGO would be a pre-planning document which systemically and systematically summarizes all the important information about the three complementary coastal governance dimensions in the municipality. Such material might be used in both ways - by its own (as a separate planning/management document) or as a tool for the development of other coastal friendly planning documents, since it would facilitate the integration of coastal issues into all other future and to-be-renewed documents.

\section{Acknowledgements}

Authors would like to acknowledge work of Latvia University colleagues who participated in the National research programme's SUSTINNO project (2014-2018) and EU BONUS programme's BaltCoast project (2015-2018), and, particularly, colleagues supporting and consulting Jurmala case study (2019-2020) Ivars Kudrenickis, Janis Lapinskis, Janis Kaulins, and Erika Lagzdina.

\section{Bibliography}

1. Ballinger, R, Cummins, V., O'Hagan, A.M., Philippe, M. (2008). The Point of COREPOINT: Improving Capacity for Integrated Coastal Zone Management in North West Europe. Report. p. 81

2. Breton, F. (2006). Report on the Use of the ICZM Indicators from the WG-ID of EC: A Contribution to the ICZM Evaluation. European Environment Agency, 63.

3. Buono, F., Soriani, S., et. al. (2015). The Difficult Road to Integrated Coastal Zone Management Implementation in Italy: Evidences from the Italian North Adriatic Regions. Ocean and Coastal Management, $114,21-31$.

4. Deboudt, P. (2012). Testing Coastal Management in France. Ocean Coastal Management, 57, 62-78.

5. Ernsteins, R. et.al. (2017a). Pro-Environmental Municipal Governance Developments in Latvia: Sustainability and Integration Principles in Practice. Proceedings of The International Scientific Conference, Vilnius Gediminas Technical University, Vilnius, Lithuania, May 2017, 308-317 pp.

6. Ernsteins, R., et.al. (2017b). Integrated Coastal Management Practice Case Studies: Deficiency of Collaboration Communication and Socio-ecological system Approaches. Conference proceedings. Economic Science for Rural Development, Jelgava, Latvia, April 2017, Issue 45, pp. 63-70.

7. Ernsteins, R., Lagzdina, E., Kudrenickis, I., Lontone-Ievina A. (2020a). Municipal Coastal Governance System Developments in Latvia: Governance Segments, Sectors and Instruments. Conference Proceedings. Latvia University of Life Sciences and Technologies, Jelgava, Latvia, May 2020.

8. Ernsteins, R., Stokmane, M., Pudans, A. (2020b). Local Coastal Governance Assessment Development: Coastal Governance Framework Reporting. Economic Science for Rural Development: Conference Proceedings. Latvia University of Life Sciences and Technologies, May 2020, Jelgava, Latvia.

9. Hopkins, S., Bailly, D. et al. (2012). A Systems Approach Framework for the Transition to Sustainable Development: Potential Value Based Coastal Experiments, Ecology and Society, Vol. 17, Issue 3, p.39.

10. Kalpakis, V., Kokkos, N., Pisinaras, V., Sylaios, G. (2018). An Integrated Coastal Zone Observatory at Municipal Level: The Case of Kavala Municipality, Greece. J. of Coastal Conservation, 23, 149-162.

11. Kaulins, J., Ernsteins, R. et.al. (2017). Municipal Thematical and Territorial Indicator Systems for Sustainable Socio-Ecological Coastal Governance. Proceedings of The International Scientific Conference, Vilnius Gediminas Technical University, Vilnius, Lithuania, May 2017, 318-329 pp.

12. Klingsheim, J. M. (2011). Norwegian Policies in ICZM and Requirements for Data and Methods, Adapting to Climate change. BLAST - Bringing Land and Sea Together, 1-20.

13. National Long-Term Public Infrastructure Thematic Plan for the Coastal Area of the Baltic Sea (2016). Ministry of Environmental Protection and Regional Development, Republic of Latvia

14. O'Hagan A.M., Ballinger R. (2009). Coastal Governance in North West Europe: An Assessment of Approaches to the European Stock take. Marine Policy, 33(6), 912-922.

15. Pommere, I., Osniece, K., Lontone-Ievina, A., Ernsteins, R. (2018). Municipal Integrated Coastal Management: Local Participatory Multi-thematical Monitoring Development. Journal of Social Sciences, Regional Formation and Development Studies, pp. 106-118. 
16. Portman, M. E., Esteves, L.S., Le, X.Q., Khan, A.Z. (2012). Improving Integration for Integrated Coastal Zone Management: An Eight Country Study. Science of the Total Environment, 439, 194-201.

17. Protection Zone Law. Republic of Latvia, Parliament (Saeima) on 05.02.1997.

18. Stojanovic, T.A. (2007) Guidelines for Implementing Local Information Systems at the Coast. COREPOINT and Cardiff University, Cardiff. p. 35.

19. Strategy for Coastal Spatial Development for 2011-2017 (2011). Ministry of Environmental Protection and Regional Development, Republic of Latvia (Coastal Spatial Strategy 2011)

20. Thetis (2011). Analysis of Member States Progress Reports on Integrated Coastal Zone Management (ICZM): Final Report. European Commission - DG Environment, 357.

21. Truksans, D., Biezina, L., Zilniece, I., Ernsteins, R. (2020). Municipal Pro-environmental Governance Revitalization: Expanding Blue and Green Flag Complementing Instruments, Proceedings, International Multidisciplinary Scientific GeoConference, SGEM, Albena, Bulgaria, 2020, 5.1, pp. 545-560. 